\title{
MARATTIOPSIS VODRAZKAE SP. NOV. (MARATTIACEAE) FROM THE CAMPANIAN OF THE HIDDEN LAKE FORMATION, JAMES ROSS ISLAND, ANTARCTICA.
}

\author{
JIŘÍ KVAČEK \\ National Museum, Prague, Department of Palaeontology, Václavské nám. 68, 11579 Praha 1, the Czech Republic; e-mail: \\ jiri.kvacek@nm.cz
}

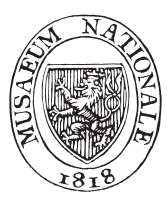

Kvaček, J. (2014): Marattiopsis vodrazkae sp. nov. (Marattiaceae) from the Campanian of the Hidden Lake Formation, James Ross Island, Antarctica. - Acta Mus. Nat. Pragae, Ser. B, Hist. Nat., 70(3-4): 211-218, Praha. ISSN 1804-6479.

\begin{abstract}
A new fossil eusporangiate fern Marattiopsis vodrazkae J. Kvaček, sp. nov. has been recovered from the Hidden Lake Formation, the Campanian of James Ross Island, Antarctica. Its fertile and sterile pinnules are described and compared to the other species of the fossil genus Marattiopsis Schimper and the living genera Marattia, Ptisana and Eupodium (Marattiaceae). In contrast to the other species of the genus Marattiopsis, M. vodrazkae is characterised by stalked synangia, a smaller number of sporangia per synangium, generally small sized pinnules, and the absence of venuli recurrentes. It shows a mosaic of characters present in the living Marattiaceae: it shares stalked sporangia with the genus Eupodium and some species of Marattia and exhibits a suture (an abscission scar at pinnule bases), a character typical for the genus Ptisana. Additionally, M. vodrazkae provides important palaeoenvironmental signals for climate reconstructions, arguing for warm (paratropical to warm-temperate) and humid climatic conditions on the Antarctic Peninsula and adjacent volcanic islands during the Campanian.
\end{abstract}

Marattiaceae, Campanian, Cretaceous, James Ross Island, Antarctica

Received November 3, 2014

Issued December 2014

\section{Introduction}

Ferns of the family Marattiaceae belong to the most ancient groups of pteridophytes. They represent an early diverging group of eusporangiate ferns (e.g. Smith et al. 2006, Taylor et al. 2009) with several genera having records extending into the mid-Carboniferous (Millay 1990). The most remarkable synapomorphies of the marattioids are large, thick walled sporangia fully or partially fussed into synangia (Murdock 2008).

The extensive fossil record of the Marattiaceae comes particularly from the Permian, Triassic and Jurassic strata of Europe (e.g. Lundblad 1950, Harris 1961, van Konijnenburg van Citter 1975), and Asia (e.g. Kawasaki 1939, Kilpper 1964, Hill et al 1985, Schweitzer et al. 1997, Wang 1999). Their occurrences in the Southern Hemisphere are restricted to Argentina (e.g. Arrondo and Petriella 1980, Escapa et al. 2014), Brazil (Tavares et al. 2014) and Antarctica (Delevoryas et al. 1992). Since the Cretaceous their fossil record is much reduced (e.g. Collinson 2001). Therefore the record described in this paper of the Marattiaceae from the Late Cretaceous of Antarctica is of particular interest.

\section{Material and methods}

The studied material is derived from the Late Cretaceous locality on James Ross Island (Kvaček and Sakala 2012, Sakala and Vodrážka 2014). The material comes from the Hidden Lake Formation of the Gustav Group in the Larsen Basin, sometimes termed the James Ross Basin (Elliot 1988).
The basin was formed as a back-arc basin during Late Mesozoic - Early Cenozoic (e.g., Hathway 2000). Sediments of the Hidden Lake Formation occur in the north-western part of James Ross Island (Text-fig. 1). The formation represents the lowermost unit of the Gustav Group (Whitham et al., 2006). It consists of a $400 \mathrm{~m}$ thick layer of coarse-grained volcanoclastic conglomerates, sandstones, siltstones and mudstones (Whitham et al. 2006). The sand-dominated sediments are interpreted as deposits of a shallow marine deltaic environment within a fan delta shelf setting (Elliot 1988, Pirrie 1991). Palaeontological and Sr-isotope data suggest a Coniacian age for the formation (e.g. McArthur et al. 2000, Riding and Crame 2002, Crame et al. 2006).

The flora of the Hidden Lake Formation is dominated by angiosperms (Hayes et al. 2005, Cantrill and Pool 2012, Sakala and Vodrážka 2014). However, pteridophytes are also well represented (Kvaček and Sakala 2012). A preliminary description of the Hidden Lake Formation flora is in preparation by the present author (Kvaček and Vodrážka in prep.).

This study is based on the collections gathered during austral summer seasons between December 2008 - March 2009 by the present author and between January - March 2010 by Radek Vodrážka (CGS), whilst at the Czech Antarctic Johann Gregor Mendel Research Station (63 48' 5.6" S, 57 53' 5.6" W) situated on the northern coast of James Ross Island. The material is housed in the Czech Geological Survey (CGS) and the Instituto Antártico Argentino (IAA) in Buenos Aires.

The studied specimens were photographed using a Canon EOS 6D camera with a Canon 100 macro lens and Olympus 


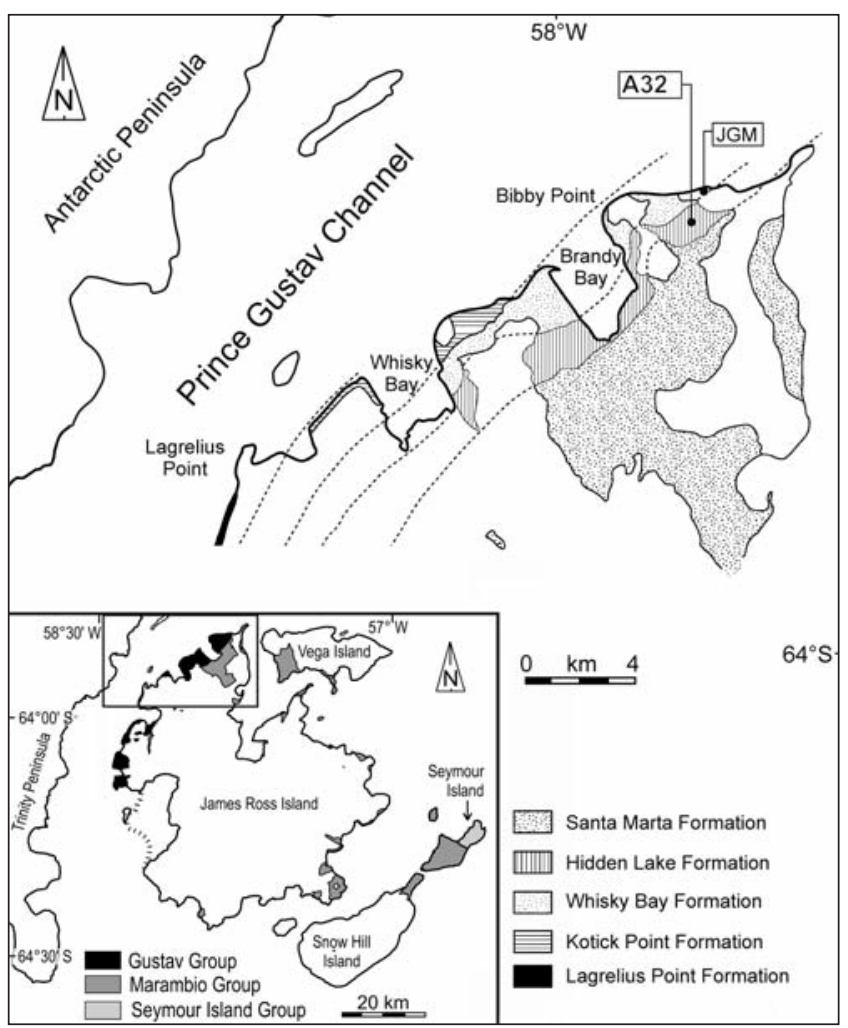

Text-fig. 1. Geographical and geological situation in the James Ross Island region. The locality No. 32 and the position of the Johann Gregor Mendel Czech Antarctic Station (JGM) are indicated. Modified from Sakala and Vodrážka (2014).

SZX 12 stereomicroscope equipped with an Olympus DP 72 camera. Details of fossil and recent synangia and spores were documented using a Hitachi S 3700-N SEM in low vacuum mode.

\section{Systematic palaeobotany}

\section{Family Marattiaceae KAULF.}

\section{Genus: Marattiopsis SCHIMPER 1869}

Type: Marattiopsis crenulata LundBLAD 1950, typ. cons. prop. (Bomfleur et al. 2013).

D i s c u s s i o n. Earlier records of Triassic and Jurassic members of the Marattiaceae were described under the name Marattiopsis SCHIMPER or the recent genus Marattia Sw. s.l. However, the latter genus in its earlier sense has been identified as polyphyletic (Murdock 2008) and therefore subdivided into three genera Marattia Sw s. s., Ptisana Murdock and Eupodium (J. SM.) HoOKER. Due to this fact Bomfleur et al. (2013) reintroduced the genus Marattiopsis SCHIMPER for the fossil material which could not be assigned unequivocally to either Marattia, Ptisana or Eupodium.

Marattiopsis vodrazkae J. Kvaček, sp. nov.

Pl. 1, figs $1-10$, Pl. 2, figs 1,2 here.

H o l o t y p e: CGS No. AN 491 (pl. 1, figs 1-3) designated here.
Type locality: A32-2; James Ross Island, Antarctica.

Type horizo n: Coniacian, Late Cretaceous, Hidden Lake Formation.

E t y m o l o g y: After my colleague Radek Vodrážka who intensively collected fossils on James Ross Island in the period 2009-2011.

O the r m at e ri a l: James Ross Island, Antarctica locality A32-2: AN 492, AN 495, AN 506ab (CGS); IAA 005-008, IAA 022; locality A32-1: IAA 083; locality A32-3: IAA 043

Diagnosis. Isolated pinnules oblong to oblonglanceolate, tapering gradually towards the apex; base with basiscopic auricle and short petiolule; apex acute, pinnule margins varying from undulate, denticulate to dentate, venation simply pinnate, eucamptodromous consisting of one vein order. Lateral veins commonly forking immediately at, or near, the midrib, leaving the midrib at an acute angle. Synangia shortly stalked consisting of two deeply divided valves. Each valve consisting of 5-6 sporangia. Spores in situ monolete, granular to delicately rugate.

Description. The holotype (Pl. 1, fig. 1) is an exceptionally well preserved specimen showing two synangia born on a pinnule fragment $(40 \times 50 \mathrm{~mm})$. One synangium is broken longitudinally, another one perpendicularly (Pl.1, fig. 1). The synangia are arranged in the central part of the pinnule lamina (P1. 1, fig. 2). The longitudinally broken synangium (Pl. 1, fig. 3) shows an elliptic valve with six sporangia. The valve is $1.6 \mathrm{~mm}$ long and $1 \mathrm{~mm}$ high. Each sporangium is elongate ovoid, $1 \mathrm{~mm}$ long and $0.2-0.5 \mathrm{~mm}$ in diameter. The synangium length occupies about $20-35 \%$ of the pinnule width (Pl.1, fig. 1 ). In the transversal section the synangium is deeply divided into two valves, bilaterally symmetrical and spindle-shaped. The valves are erect, ovate, pointed in apical parts. Both valves are born on a short common stalk $0.2 \mathrm{~mm}$ in length (Pl. 1, fig. 1). The sporangium walls consist of elongate cells (Pl. 2, fig. 1). Spores in situ 25-32 $\mu \mathrm{m}$ in diameter are probably not mature. They are tightly pressed together and arranged in diades (Pl. 2, fig. 2). They are monolete, ellipsoid in equatorial outline showing a granular, rugate exospore (P1. 2, fig. 2).

The lamina fragment of the holotype shows the same venation pattern and dentate margin as other isolated pinnules. Sterile material is typified by the paratype (Pl. 1, fig. 7) showing an oblong-lanceolate sterile pinnule nearly $20 \mathrm{~mm}$ in length with a vein density of 14 veins per cm. Its base is asymmetrical with a relatively well pronounced basiscopic auricle. Venation of each pinnule is pinnate, the robust main midrib reaching the pinnule apex. Robust lateral veins in basal and medial parts of the pinnule fork immediately at, or near, the midrib. Each lateral vein terminates in a tooth. Paired veins unite two adjacent teeth into pairs which form a characteristic double dentate pattern (see Pl. 1, fig. 7).

Other material comprises a number of isolated pinnules. The fertile pinnules (IAA 006, 007) usually do not have preserved synangia (Pl. 1, fig. 10). However, their scars or impressions show an arrangement of six to ten synangia in 
Table 1. Comparison of species diagnostic characters of the genus Marattiopsis.

\begin{tabular}{|c|c|c|c|c|c|c|c|}
\hline \multirow[b]{2}{*}{ taxon } & \multicolumn{7}{|c|}{ Diagnostic characters } \\
\hline & pinnule base & $\begin{array}{l}\text { pinnule } \\
\text { margin }\end{array}$ & \begin{tabular}{|c|}
$\begin{array}{c}\text { no. of veins } \\
\text { per } \mathrm{cm}\end{array}$ \\
\end{tabular} & \begin{tabular}{|c|} 
venuli \\
recurrentes
\end{tabular} & \begin{tabular}{|}
$\begin{array}{c}\text { synangium } \\
\text { length/ } \\
\text { pinnule width }\end{array}$ \\
\end{tabular} & \begin{tabular}{|c|} 
no. of spo- \\
rangia pairs \\
per synangium
\end{tabular} & reference \\
\hline $\begin{array}{l}\text { M. aganzhenensis (Yang et al) Escapa, } \\
\text { Bomfleur, Cuneo, Scasso }\end{array}$ & rounded & entire & $10-16$ & absent & 12.5 & 20 & $\begin{array}{l}\text { Yang et al. } \\
2008\end{array}$ \\
\hline M. anglica Thomas & $\begin{array}{c}\text { contracted } \\
\text { and rounded }\end{array}$ & entire & $10-12$ & not known & 33 & 30 & \begin{tabular}{|l|} 
van Konij- \\
nenburg-van \\
Cittert 1975 \\
\end{tabular} \\
\hline M. angustifolia Prynada & unknown & $\begin{array}{l}\text { entire- } \\
\text { undulate }\end{array}$ & 13 & present & 25 & unknown & Prynada 1938 \\
\hline M. asiatica Kawasaki & rounded & $\begin{array}{l}\text { entire- } \\
\text { undulate }\end{array}$ & $13-16$ & present & 17 & $10-40$ & $\begin{array}{l}\text { Kawasaki } \\
1939 \\
\end{array}$ \\
\hline $\begin{array}{l}\text { M. barnardii (Schweitzer, van Konijnen- } \\
\text { burg - van Cittert, van der Burgh) Escapa, } \\
\text { Bomfleur, Cuneo, Scasso }\end{array}$ & $\begin{array}{l}\text { cordate, } \\
\text { slightly } \\
\text { auriculate }\end{array}$ & $\begin{array}{l}\text { undulate- } \\
\text { serrate }\end{array}$ & $8-14$ & absent & $20-30$ & $8-16$ & $\begin{array}{l}\text { Schweitzer } \\
\text { et al. } 1997\end{array}$ \\
\hline M. crenulata Lundblad & unknown & $\begin{array}{l}\text { crenulate- } \\
\text { undulate }\end{array}$ & 9 & present & $5-6$ & 10 & $\begin{array}{l}\text { Lundblad } \\
1950\end{array}$ \\
\hline $\begin{array}{l}\text { M. curvinervis (Lorch) Escapa, Bomfleur, } \\
\text { Cuneo, Scasso }\end{array}$ & unknown & unknown & $26-34$ & present & $20-33$ & unknown & Lorch 1967 \\
\hline $\begin{array}{l}\text { M. hoerensis Schimper (Schimper) } \\
\text { Schimper }\end{array}$ & $\begin{array}{c}\text { asymetrically } \\
\text { auriculate }\end{array}$ & entire-dentate & $8-14$ & present & 20 & unknown & $\begin{array}{l}\text { Schimper } \\
1869\end{array}$ \\
\hline M. intermedia (Münster) Weber & unknown & unknown & $12-16$ & unknown & unknown & unknown & Weber 1968 \\
\hline M. muensteri (Göppert) Schimper & rounded & entire & 10 & present & $10-20$ & uknown & $\begin{array}{l}\text { Schimper } \\
1869\end{array}$ \\
\hline $\begin{array}{l}\text { M. patagonica Escapa, Bomfleur, } \\
\text { Cuneo, Scasso }\end{array}$ & $\begin{array}{c}\text { asymetrically } \\
\text { auriculate }\end{array}$ & $\begin{array}{l}\text { undulate- } \\
\text { serrulate }\end{array}$ & $8-16$ & present & $12-20$ & $8-20$ & $\begin{array}{l}\text { Escapa et al. } \\
2014\end{array}$ \\
\hline M. vodrazkae sp. nov. & $\begin{array}{c}\text { asymetrically } \\
\text { auriculate }\end{array}$ & $\begin{array}{l}\text { serrate, } \\
\text { undulate }\end{array}$ & $10-14$ & absent & $20-35$ & $5-6$ & $\begin{array}{l}\text { Kvaček } \\
\text { herein }\end{array}$ \\
\hline
\end{tabular}

three to five pairs per pinnule. They were born on lateral veins nearby the midrib (Pl. 1, fig. 10). With respect to the sterile pinnules, a completely preserved pinnule is invaluable , with a low vein density (10 veins per $\mathrm{cm})$, a denticulate undulate margin, asymmetrical auriculate base and acute apex (Pl. 1, fig. 8). Further material (Pl. 1, fig. 4) displays pinnule fragments $(18 \times 1 \times \quad 8$ mm) showing a nearly symmetrical, slightly cordate base with a delicate fragment of petiolule and fragmentarily preserved apex. Marginal teeth are blunt, inconspicuous forming an undulate margin. The specimen AN 506a (Pl. 1, fig. 5) shows an undulatedenticulate margin and asymmetrically auriculate base with a well pronounced short petiolule. The specimen AN 495 shows an apical fragment of a pinnule with bifurcating terminal part of the midrib (Pl. 1, fig. 6). The specimen IAA 008 shows a well preserved asymmetrical auricule with a suprabasal vein bent backwards (Pl. 1, fig. 9).

Discus sion. Marattiopsis vodrazkae is known only from the Hidden Lake Formation on James Ross Island. It is unusual within the genus in having remarkably smaller pinnules than the rest of the Marattiopsis species. However, its typical type of sporangia forming synangia and the characteristic occurrence of only isolated pinnules with basiscopic auricles argue for inclusion of this material into the genus Marattiopsis.

The type species Marattiopsis crenulata LUNDBLAD from the Triassic of Sweden (Lundblad 1950) proposed by Bomfleur et al (2013) differs from the present material in having marginally arranged synangia and remarkably larger sized pinnules. It also differs in lacking short stalked synangia.

Yang (et al 2008) and Esacpa (et al 2014) suggested a list of diagnostic characters which can help us compare $M$. vodrazkae sp. nov. with the other species of the genus. The characters are in particular the type of pinnule margin, vein density, presence or absence of venuli recurrentes, number of septa per sporangium and ratio of synagium length to pinnule width (Tab. 1). M. vodrazkae differs from all of the listed species in several important characters. It has short stalked synangia, 5-6 septa pairs per synangium and remarkably small pinnules. As it is clear from Table $1 \mathrm{M}$. vodrazkae differs from Marattiopsis aganzhenensis (YANG, Wang, Pfefferkorn) Escapa, Bomfleur, Cuneo, Scasso. from the Early Jurassic of China (Yang et al. 2008) and $M$. anglica THOMAs from the Jurassic of Great Britain (van Konijnenburg van Cittert 1975) in absence of entire margined pinnules, round, symmetrical base and lower number of sporangia per valve. M. vodrazkae differs from $M$. angustifolia PRYNADA from the Jurassic of Russia (Prynada 1938) and M. asiatica KAWASAKI from the Triassic of Korea, Japan, Vietnam and China (Kawasaki 1939, Wang 1999), from M. curvinervis (LORCH) ESCAPA, BOMFLEUR, CUNEO, SCASSO from the Jurassic of Israel (Lorch 1967), from $M$. hoerensis (SCHIMPER) SCHIMPER from the Triassic of Sweden (Schimper 1869), from M. muensteri (GÖPPERT) SCHIMPER from the Rhaeto-Liassic of Germany, from M. intermedia (MÜNSTER) WeBER from the Rhaeto-Liassic of Bayreuth (Weber 1968) and from M. patagonica EsCAPA, BOMFLEUR, CUNEO, SCASSO from the Early Jurassic of Argentina (Escapa et al. 2014) in the absence of venuli recurrentes and lower number of sporangia per valve. M. vodrazkae differs from $M$. barnardii (SCHWEITZER, VAN KONIJNENBURG - VAN CitTERT, VAN DER Burgh) Escapa, Bomfleur, Cuneo, Scasso from the Rhaeto-Liassic of Iran (Schweitzer et al. 1997) in having a lower number of sporangia per valve, more asymmetrical bases and smaller size of pinnules. Those species of 
Marattiopsis based on sterile foliage only are not compared with $M$. vodrazkae due to lack of the important synangia characters .

\section{Comparison with extant material}

Within extant taxa, M. vodrazkae shares characters with all three species assigned previously to Marattia s. 1. Eupodium, Ptisana and Marattia s.s. It shares stalked synangia with the genus Eupodium. However, M. vodrazkae is most similar to the latter genera Ptisana and Marattia s.s. The presence of a mosaic of characters present in both the above genera does not allow its attribution to either Ptisana or Marattia. Within the genus Marattia s.s. the species Marattia douglasii (P1. 2, figs 3, 4, 8) shows very similar pinnules with the same pattern of marginal teeth (notably the tendency to form double teeth), but its sporangia are compact and show only shallow dissection. On the other hand, some species of Marattia s.s. e.g. M. cicutifolia have short stalked synangia as does M. vodrazkae (Murdock 2008). M. vodrazkae seems to be most similar to some species of the genus Ptisana in having a very similar type of synangia. Also the presence of sutures (abscission scars) at the pinnule bases, characteristic of all species of Ptisana, argues for a closer relationship. The latter character is an interpretation of the fact that the pinnules of Marattiopsis always occur as fragmented isolated pinnules (Escapa et al. 2014). Ptisana sylvatica (P1. 2, figs 5-7) shows deeply dissected synangia possessing the same shape and size as Marattiopsis vodrazkae (compare P1. 2, fig. 1 and fig. 5). However, pinnules of $P$. sylvatica have a serrulate margin and simple veins, characters which are not present in $M$. vodrazkae. This mosaic of characters of both Marattia s.s and Ptisana present in M. vodrazkae resulted in a decision to assign the material to the rather broadly understood genus Marattiopsis.

\section{Palaeoclimatic and palaeoecological remarks}

M. vodrazkae might be a quite useful climate indicator for the Hidden Lake Formation. It can be used as an important taxon for the NLR method and provides parallel proxy data in addition to CLAMP analysis published by Hayes et al. (2005). From their data, mean annual temperature (MAT) for the Hidden Lake Formation is $13-21^{\circ} \mathrm{C}$ (mean $17^{\circ} \mathrm{C}$ ) and annual precipitation 594-2142 $\mathrm{mm}$.

Recent members of the family Marattiaceae are typical elements of tropical rain forests (Murdock 2008). However, some species also occur in paratropical, very rarely maritime warm temperate climates (Christenhusz 2007, fig. 2). Tropical to paratropical climates are generally reconstructed also for fossil species of the Marattiaceae (Escapa et al. 2014).

As an example of the extremely cool climate tolerated by the Marattiaceae is the maritime warm temperate climate of New Zealand (MAT to $10-16^{\circ} \mathrm{C}$, NIWA 2014). The northern island of New Zealand hosts the marattioid fern Ptisana salicina. This is the only species of the family present in New Zealand. In a preliminary reconstruction, one might assume that this example could be the closest possibility for reconstruction of climate conditions of the Hidden Lake
Formation. This assumption is in concert with conclusions of Hayes et al. (2005) who interpreted the climate of the Hidden Lake Formation as warm temperate (MAT $17^{\circ} \mathrm{C}$ ). Also their rather controversial estimates of high precipitation (annual precipitation of up to $2142 \mathrm{~mm}$, Hayes et al. 2005) appear to be more realistic in the light of typical environments for marattioid ferns.

The palaeoecology of the Hidden Lake Formation flora is not yet fully understood. From preliminary studies summarised in Cantrill and Pool (2012) and reports by Kvaček and Sakala (2012), Kvaček and Vodrážka (in prep.) the vegetation can be reconstructed as warm temperate to paratropical forest rich in fern and bryophyte understory. The above mentioned palaeoclimatic proxy data (Hayes et al. 2005), presence of numerous bryophytes and ferns, including Marattiaceae, strongly argue for rain forest either warm temperate, or paratropical growing on the Antarctic Peninsula during the Campanian.

\section{Conclusions}

A new species, Marattiopsis vodrazkae J. Kvaček sp. nov., is erected to accommodate isolated fertile and sterile pinnules of marattioid fern material from the Campanian Hidden Lake Formation. It is recognised in having dentateundulate pinnules with simple pinnate venation and deeply dissected short stalked synangia consisting of 5-6 pairs of sporangia. The present paper reports on the only known megafossil of the Cretaceous Marattiopsis in Antarctica. Most other species of Marattiopsis differ from the studied material in having sessile synangia or of unknown position, higher number of sporangia per synangium and much larger and elongate pinnules. In general morphology of the pinnules and the number of sporangia per synangium Marattiopsis vodrazkae remains close to the species of the recent genera Ptisana and Marattia s.s. and may represent a stem group of those marattioid ferns.

The occurrence of $M$. vodrazkae has quite important climatic and ecological significance. It confirms predicted estimates for the climate of the Hidden Lake Formation by earlier authors (Hayes et al. 2005) and suggests warm temperate to paratropical rain forest as a possible type of reconstructed vegetation for this part of Antarctica.

\section{Acknowledgements}

I am grateful to Radek Vodrážka for providing me with the fossils, Ota Šída (National Museum) and Joao Paulo Condack (Herbarium of Rio de Janeiro) who provided access to herbaria for studies of comparative recent material. I also thank Johanna van Konijnenburg van Cittert, Vasilis Teodoridis and my father Zlatko Kvaček for valuable comments. In addition I am grateful to Lenka Váchová and Martin Valent for their help with photograpical documentation of the material. This study was supported by the Ministry of Culture of the Czech Republic (grant no. DKRVO 2014/05, 00023272) and the Research and Development Project of the Ministry of Environment of the Czech Republic No. SPII 1a9/23/07. 


\section{References}

Arrondo, O. G., Petriella, B. (1980): Alicura, nueva localidad plant_1fera Li_asica de la Provincia de Neuqu_en, Argentina. - Ameghiniana, 17: 200-215.

Bomfleur, B., Escapa, I. H., Taylor, E. L., Taylor, T. N. (2013): Proposal to conserve the name Marattiopsis (fossil Marattiaceae) with a conserved type. - Taxon, 62: 637-638. http://dx.doi.org/10.12705/623.27

Cantrill, D. J., Pool, I. (2012): The vegetation of Antarctica through geological time. - Cambridge University Press, Cambridge, 480 pp. http://dx.doi.org/10.1017/CBO9781139024990

Christenhusz, M. J. M. (2007): Evolutionary History and Taxonomy of Neotropical Marattioid Ferns: Studies of an Ancient Lineage of Plants. - Biologica - Geographica - Geologica, 216: 1-78.

Collinson, M. E. (2001): Cainozoic ferns and their distribution. - Brittonia, 53: 173-23. http://dx.doi.org/10.1007/BF02812700

Crame, J.A., Pirrie, D., Riding, J.B. 2006. Mid-Cretaceous stratigraphy of the James Ross Basin, Antarctica,. In: Francis, J. E. Pirrie, D., Crame, J. A. (eds.), Cretaceous-Tertiary High-Latitude Palaeoenvironments, James Ross Basin, Antarctica. pp. 7-19, Geological Society Special Publications, 258. London.

Delevoryas, T., Taylor, T. N., Taylor, E. L. (1992): A marattialean fern from the Triassic of Antarctica. Review of Paleobotany and Palynology, 74: 101-107. http://dx.doi.org/10.1016/0034-6667(92)90140-C

Elliot, D.H. (1988): Tectonic setting and evolution of the James Ross Basin, northern Antarctic Peninsula. - In: Feldmann, R.M., Woodburne, M.O. (eds), Geology and paleontology of Seymour Island, Antarctic Peninsula, Geological Society of America Memoir, 169, pp. 541-555. http://dx.doi.org/10.1130/MEM169-p541

Escapa, I.H., Bomfleur, B., Cuneo, N. R., Scasso, R. (2014): A new marattiaceous fern from the Lower Jurassic of Patagonia (Argentina): the renaissance of Marattiopsis. - Journal of Systematic Palaeontology, 9. http://dx.doi.org/10.1080/14772019.2014.936974

Harris, T. M. (1961): The Yorkshire Jurassic Flora. I. Thallophyta-Pteridophyta. - British Museum (Natural History), London, 212 pp.

Hathway, B. (2000): Continental rift to back-arc basin: Jurassic-Cretaceous stratigraphical and structural evolution of the Larsen Basin, Antarctic Peninsula. Journal of the Geological Society of London, 157: 417-432. http://dx.doi.org/10.1144/jgs.157.2.417

Hayes, P., A., Francis, J. E., Cantrill, D. J., Crame, J., A. (2005): Palaeoclimate analysis of Late Cretaceous angiosperm leaf floras, James Ross Island, Antarctica. In: Francis, J., E., Pirrie, J. E., Crame, J. A. (eds), Cretaceous-Tertiary high-latitude palaeoenvironments, James Ross Basin, Antarctica, Geological Society, London, Special Publications, 258, pp. 49-62.

Hill, C. R.,Wagner, R. H., El-Khayal, A. A. (1985): Quasimia gen. nov., an early Marattia-like fern from the Permian of Saudi Arabia. - Scripta Geologica, 79(2): 1-69.

Kawasaki, S. (1939): Second addition to the older Mesozoic plants in Korea. - Bulletin of the Geological Survey of Korea, 4: 1-69.
Kilpper, K. (1964): Über eine Rät/Lias Flora aus dem nördlichen Abfall des Elbrus Gebirges in Nord Iran, 1. Bryophyta und Pteridophyta. - Palaeontographica Abt. B, 114: 1-78.

Kvaček, J., Sakala, J. (2012): Late Cretaceous flora of James Ross Island (Antarctica) - preliminary report. - Czech Polar Reports 1(2): 96-103. http://dx.doi.org/10.5817/CPR2011-2-9

Kvaček, J. and Vodrážka, R. (in prep.): Late Cretaceous flora of the Hidden Lake Formation, James Ross Island (Antarctica), its biostratigraphy and palaeoecological implications - preliminary report. Cretaceous Research.

Lorch, V. (1967): A Jurassic florule from Sinai. - Israel Journal of Botany, 16: 29-37.

Lundblad, B. (1950): Studies in the Rhaetic-Liassic floras of Sweden 1. - Kunglige Svenska Vetenskapsakademiens Handlingar, 1(8): 1-82.

McArthur, J. M., Crame, J. A., Thirlwall, M. F. (2000): Definition of Late Cretaceous stage boundaries in Antarctica using strontium isotope stratigraphy. - Journal of Geology, 108: 623-640. http://dx.doi.org/10.1086/317952

Millay, M. A. (1990): Studies of Palaeozoic marattialean ferns: Scolecopteris globiforma n. sp. from the Stephanian of France. - Review of Palaeobotany and Palynology, 63: 163-171. http://dx.doi.org/10.1016/0034-6667(90)90012-8

Muenster, G. (1836): Über einige neue Pflanzen in der Keuper Formation bei Bayreuth. - Neues Jahrbuch für Mineralogie, Geognosie, Geologie und Petrefaktenkunde, 7: 509-517.

Murdock, A. G. (2008): A taxonomic revision of the eusporangiate fern family Marattiaceae, with description of a new genus Ptisana. - Taxon, 57: 737-755.

NIWA (2014): Climate data and activities. https://www.niwa.co.nz/education-and-training/schools/ resources/climate

Pirrie, D. (1991): Controls on the petrographic evolution of an active margin sedimentary sequence: the Larsen Basin, Antarctica. - In: Morton, A. C., Todd, S. P., Haughton (eds), Developments in Sedimentary Provenance studies, Geological Society of London Special Publication, 57, pp. 231-249. London.

Prynada, B. D. (1938): Jurassic Flora of the Emba Region. -Problems in Palaeontology, vol. 4, pp. 363-404, Moscow. (in Russian)

Riding, J. B., Crame, J. A. (2002): Aptian to Coniacian (Early-Late Cretaceous) palynostratigraphy of the Gustav Group, James Ross Basin, Antarctica. Cretaceous Research, 23: 739-760. http://dx.doi.org/10.1006/cres.2002.1024

Sakala, J., Vodrážka, R. (2014): A new species of Antarctoxylon: a contribution to the early angiosperm ecosystem of Antarctica during the late Cretaceous. Antarctic Science, 26(4): 371-376. http://dx.doi.org/10.1017/S095410201300076X

Schimper, W. P. (1869): Traite de Paleontologie vegetale ou la flore du monde primitive dans ses rapports avec les formations geologiques et la flore du monde actuel. Baillere et Fils ed., Paris, 738 pp. 
Schweitzer, H. J., van Konijnenburg - van Cittert, J. H. A., van der Burgh, J. (1997): The Rhaeto-Jurassic flora of Iran and Afghanistan, 10 Bryophyta, Lycophyta, Sphenophyta, Pteridophyta - Eusporangiate and Protoleptosporangiate. - Palaeontographica Abt. B, 243: 103-192.

Smith, A. R., Pryer, K. M., Schuettpelz, E., Korall, P., Schneider, H. , Wolf, P. G. (2006): A classification for extant ferns. - Taxon, 55: 705-731. http://dx.doi.org/10.2307/25065646

Tavares, T. M. V., Rohn, R., Rößler, R., Noll, R. (2014): Petrified Marattiales pinnae from the Lower Permian of North-Western Gondwana (Parnaíba Basin, Brazil). Review of Palaeobotany and Palynology, 201: 12-28. http://dx.doi.org/10.1016/j.revpalbo.2013.09.002

Taylor, T.N., Taylor, E.L., Krings M. (2009): Paleobotany. The Biology and Evolution of Fossil Plants. - Burlington MA, London, San Diego CA, New York NY, Elsevier/ Academic Press Inc., xxi +1230 pp.

Van Konijnenburg-van Cittert, J. H. A. (1975): Some notes on Marattia anglica from the Jurassic of Yorkshire. Review of Palaeobotany and Palynology, 20: 205-214. http://dx.doi.org/10.1016/0034-6667(75)90021-4

Vodrážka, R., Crame, A. (2011): First fossil sponge from Antarctica and its palaeobiogeographical significance. Journal of Paleontology 85 (1): 48-57. http://dx.doi.org/10.1666/10-069.1

Wang, Y. D. (1999): Fertile organs and in situ spores of Marattia asiatica (Kawasaki) Harris (Marattiales) from the Lower Jurassic Hsiangchi Formation in Hubei, China. - Review of Palaeobotany and Palynology, 107: 125-144. http://dx.doi.org/10.1016/S0034-6667(99)00025-1

Weber, R. (1968): Die fossile Flora der Rhaet-LiasÜbergangsschichten von Bayreuth (Oberfranken) unter besonderer Berücksichtigung der Coenologie. Erlanger geologische Abhandlungen, 72: 1-73.

Whitham, A. G., Inneson, J. R., Pirrie, G. D. (2006): Marine volcanoclastics of the Hidden Lake Formation (Coniacian) of James Ross Island, Antarctica: an enigmatic element in the history of a back-arc basin. In: Francis, J. E., Pirrie, D. and Crame, J. A. (eds), Cretaceous-Tertiary high-latitude palaeoenvironments, James Ross Basin, Antarctica, Geological Society, London, Special Publications, 258, pp. 21-47, London.

Yang, S., Wang, J., Pfefferkorn, W. (2008): Marattia aganzhenensis sp. nov. from the Lower Jurassic Daxigou Formation of Lanzhou, Gansu, China. - International Journal of Plant Sciences, 169: 473-482.

http://dx.doi.org/10.1086/526458

\section{Explanations of the plates}

\section{PLATE 1}

Marattiopsis vodrazkae J. KvAČEK, sp. nov., James Ross Island, Hidden Lake Formation

1. Holotype showing transversely broken synangium born on a dentate leaf, AN 491, scale bar $1 \mathrm{~mm}$.

2. Holotype fragment of dentate leaf bearing synangia, $A N$ 491, scale bar $3 \mathrm{~mm}$.

3. Longitudinally broken synangium, holotype, AN 491, scale bar $1 \mathrm{~mm}$.

4. Pinnule with cordate base and undulate margin, IAA 005, scale bar $5 \mathrm{~mm}$.

5. Small complete pinnule with undulate margin, AN 511b, scale bar $3 \mathrm{~mm}$.

6. Apical part of pinnule, AN 495, scale bar $3 \mathrm{~mm}$.

7. Paratype, pinnule with double dentate margin, AN 493, scale bar $4 \mathrm{~mm}$.

8. Complete pinnule with serrate margin and simple venation, IAA 022, scale bar $5 \mathrm{~mm}$.

9. Pinnule with serrate margin, IAA 008, scale bar $4 \mathrm{~mm}$.

10. Pinnule with undulate margin and remains of partly detached synangia, IAA 007, scale bar $4 \mathrm{~mm}$.

\section{PLATE 2}

Marattiopsis vodrazkae J. KVAČEK, sp. nov., James Ross Island, Hidden Lake Formation

1. Detail of synangium, holotype, AN 491, scale bar $250 \mu \mathrm{m}$.

2. Spores (arrowed), holotype, AN 491, scale bar $50 \mu \mathrm{m}$.

Marattia douglasii (C. Presl) BAKer, Hawai (Rosenstock 91, coll. NMP)

3. Synangium, scale bar $50 \mu \mathrm{m}$.

4. Monolete spores, scale bar $20 \mu \mathrm{m}$.

5. Pinnule showing double dentate margin, scale bar $5 \mathrm{~mm}$.

Ptisana sylvatica (Blume) Murdock, Cameroun, (Kurz 338, coll. NMP)

6. Synangium, scale bar $50 \mu \mathrm{m}$.

7. Pinnule showing serrulate margin, scale bar $5 \mathrm{~mm}$.

8. Monolete spores, scale bar $20 \mu \mathrm{m}$. 
PLATE 1
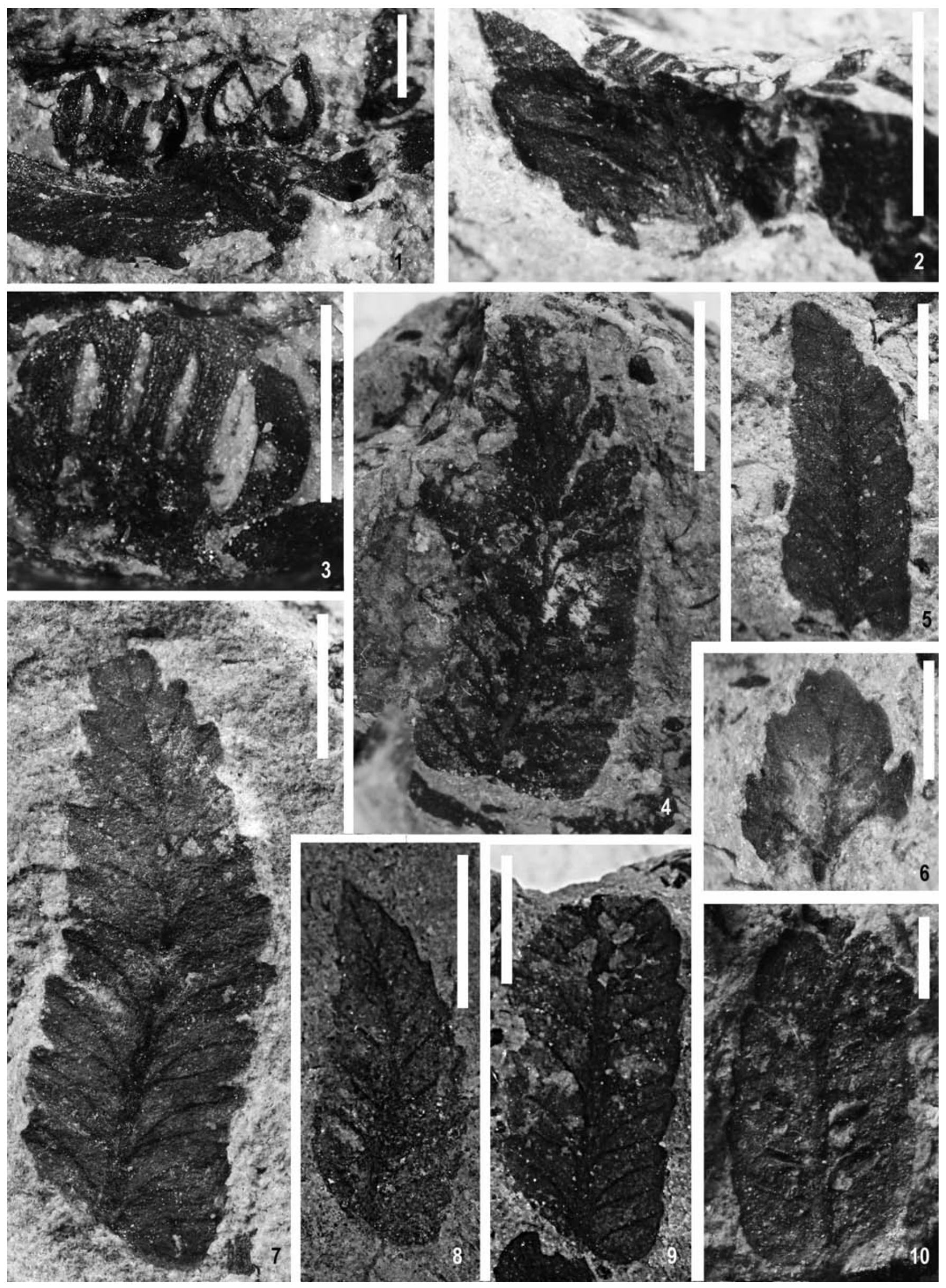
PLATE 2
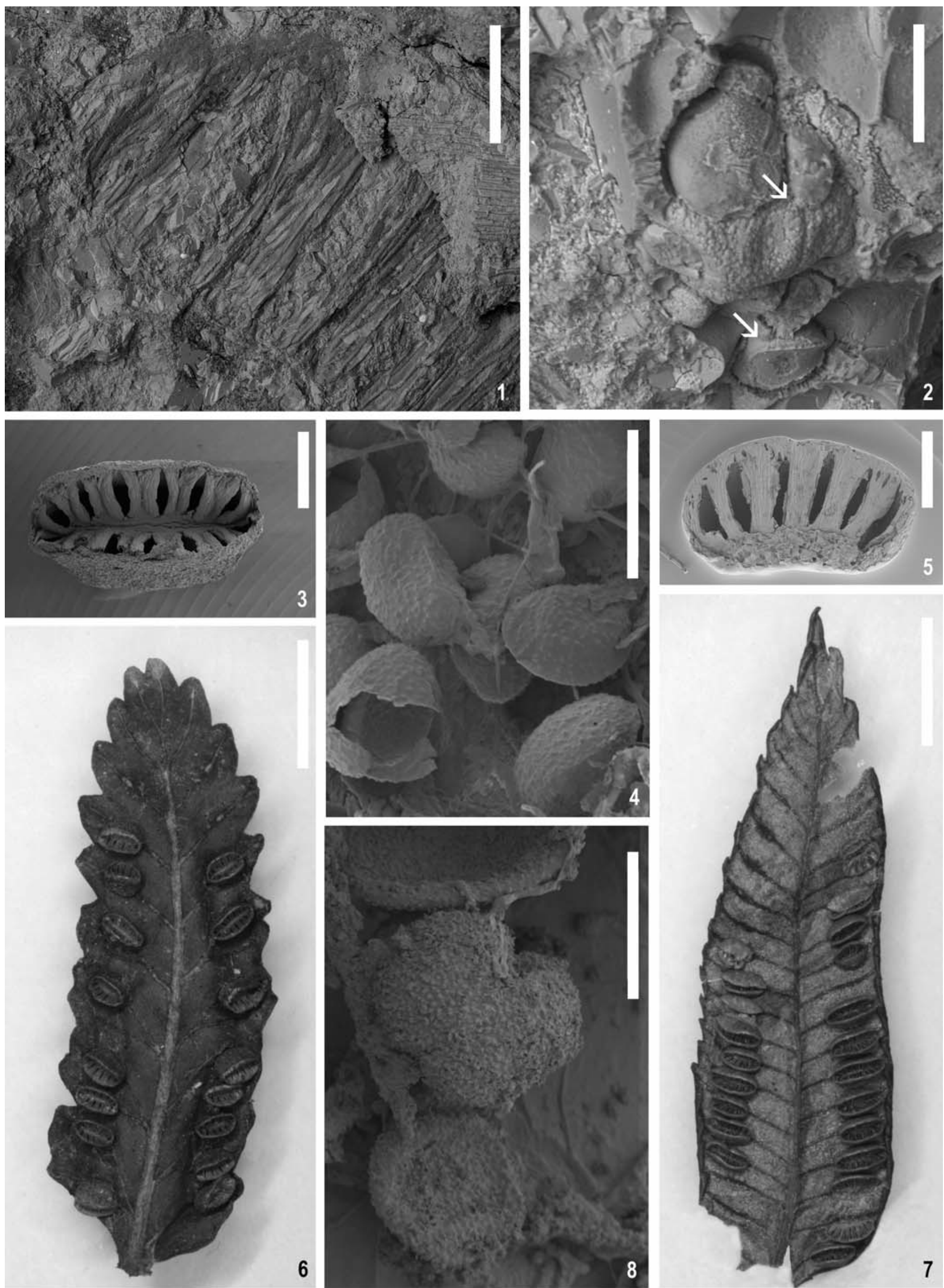